\title{
Poemética: cabine de magia
}

\author{
Poemetic: magic booth
}

\author{
Viviane Potiguara \\ Pontifícia Universidade Católica do Rio de Janeiro
}

DOI: 10.12957/mnemosine.2020.57649

Poesia\&política são ciências ímãs = xamãs = irmãs. Artes gêmeas. As duas voltadas para as vozes do povo que tanto tem a dizer, cada uma com seu jeito de ser. Política ama discursar ao megafone em meio à multidão. A poesia, por sua vez, já prefere falar baixinho no ouvido de quem escuta, à beira-mar e sob o brilho do luar. Universidade pública é terra próspera para o plantio delas. O que dá mais depende da época do ano. Que potência pode se tornar esse encontro na vida dos mais jovens. Movimentos poético, estudantil, operário, comunitário, capazes de aglomerar/contagiar tanta gente e transformar as coisas.

Por ora, e sem sabermos até quando, em função do contexto pandêmico, dependemos imensamente do circuito digital, da tecnologia, da distância segura entre os corpos para realizar qualquer movimento. Uma das tendências possíveis após essa experiência dolorosa nunca antes vista é que passemos a compreender o afeto e o abraço de um jeito mais ajustado com o valor que de fato têm. No íntimo, torço para que seja assim também com a política e a poesia - que a primeira seja mais afetuosa no fazer cotidiano, que tem sido atropelado nas corridas eleitorais, de trato numérico e contagem de votos; e que a poesia seja mais prestigiada por quem está ao redor, que se valorize efetivamente poetas e artistas em geral.

A Universidade do Estado do Rio de Janeiro, para mim, é sempre ao mesmo tempo casa e labirinto. Casa porque esbarro com gente de toda a parte, que transitam com a beleza própria das periferias e assim me sinto na Cidade de Deus. Labirinto porque não há uma sala que eu tenha que encontrar que eu não me perca! E que bom que é assim. É quando nos perdemos que há chance de encontro. Foi nessa energia de casa e labirinto que pude, muito para além da contribuição combinada, me transmutar no interior da cabine de magia: a Poemética, do LSD - Laboratório de Sensibilidades e Devires (UFRJ). Vermelha como se fosse a camisa do clube Internacional, de Porto Alegre; ou como a 
camisa do clube do América, meu time atual após me traumatizar com o Flamengo, após a morte da Elisa Samúdio. Vermelha como se fosse de esquerda ou ainda como um dos tons de Marte ou por fim uma vestimenta real de Iansã ou Xangô. Antes de adentrar a Poemética, dei algumas voltas ao redor, como quem investiga um objeto curioso. Quando fui ver, lá estava eu (dentro). Poemas contemporâneos no chão, um banquinho invisível e microfone de programa de auditório, daqueles que põe uma caixinha na cintura e que me fez sentir apresentadora de televisão experimental. O tempo mudou a maneira como escolhia passar. A intensidade do vermelho me despertou desejo incontrolável de cantoria, muito para além de querer falar um poema. Do lado de fora, acabei me desligando do zumzum do pra lá e pra cá dos estudantes de graduação e pós. Mal esperava, incorporei Roberta Carlos, deixei me sentir em ritual e cantei Emoções.

quando eu estou aqui, eu vivo este momento lindo.

Uma música que certamente é mais importante para minha avó - do que para mim. Talvez para duas gerações atrás que para a minha. Quando cantei era ao mesmo tempo um prestígio aos tempos passados - e a realização de uma vontade de adolescência incrustada. Cantar e ser ouvida por outros. Somente a cabine mágica ali poderia me oportunizar a situação em que eu me sentisse à vontade e livre a ponto de cantar Roberto Carlos no pátio de uma universidade e praticamente me fundir com meu próprio canto. Se fosse minha universidade, meu terreiro burguês, talvez não tivesse sido assim. Cantei e parecia então que eu tinha acessado um portal, de repente o externo barulhento parou em silêncio. Terminei de cantar e escutei aplausos inacreditáveis vindos de todos os lados do andar onde estávamos. Deveria haver cabines mágicas instaladas nas ruas - como política nacional de libertação da veia criativa das pessoas. O que é se adentrar uma cabine e poder não ser visto? Impulso e liberdade para se manifestar... Experimentem! Montem suas cabines como for possível. Instalem onde acreditarem que seja bom, deem o crédito ao Laboratório de Sensibilidades e Devires (LSD), mas por favor, as caracterizem de vermelho. Essa cor é fundamental em tempos de exceção.

Viviane Potiguara Programa de Pós-Graduação em Ciências Sociais da PUC-Rio E-mail: vivi.lablivre@gmail.com 